Persp. Teol. 40 (2008) 207-228

\title{
HENRI LE SAUX: NAS VEREDAS DO REAL
}

\author{
Faustino Teixeira
}

"Entraste na minha casa e

me conduziste a Ti.

Tens-me agora prisioneiro

na gruta de teu coração".

(Abhishiktânanda)

Resumo: O objetivo do artigo é traçar o percurso dialogal de Henri le Saux (Abhishiktânanda), um dos grandes pioneiros do diálogo inter-religioso no século XX. Sua peregrinação no âmbito do hinduísmo, e as questões a ela relacionadas, fornecem importantes pistas para os estudos no campo da conversação inter-religiosa. Abordam-se, entre outros temas, a sua trajetória de vida, a experiência de sua dupla pertença, o apelo do advaita (não-dualidade) e a pista da profundidade como marco essencial para o diálogo entre as religiões.

Palavras-chave: Cristianismo, Hinduísmo, Religiões, Diálogo, Pluralismo Religioso, Espiritualidade.

AвSTRACT: The article's goal is to present Henri le Saux's dialogical journey (Abhishiktânanda), one of the $20^{\text {th }}$ century's pioneers of the inter-religious dialogue. His journey in the Hinduism and the questions about it provide important clues for the field of studies on inter-religious conversation. Among other teams, it addresses his life journey, the experience of double belonging, the appeal of advaita (non-duality) and the suggestion of Spiritual depth as core for dialogue among religions.

KeY-WORDS: Christianity, Hinduism, Religions, Dialogue, Religious Pluralism, Spirituality. 


\section{Introdução}

diálogo inter-religioso reveste-se de uma importância fundamental nesse século XXI. Não há probabilidade de vislumbrar um horizonte distinto para as nações sem o cuidado em favor de caminhos alternativos de conversação e diálogo entre as distintas tradições religiosas. Uma das possibilidades de tocar o nervo desta questão é apresentar histórias de vida marcadas pela vocação dialogal. Entre os exemplos de buscadores de diálogo mais impressionantes que o século XX conheceu, destaca-se Henri le Saux (Swâmî Abhishiktânanda), o monge beneditino francês que ousou dar o obstinado salto no mistério da alteridade, vivendo uma experiência singular de imersão como cristão no mundo espiritual indiano. Como bem definiu Marie-Madeleine Davy, ele foi um "barqueiro entre duas margens $^{11}$, alguém que viveu como poucos a aventura da liminaridade. Para Raimon Panikkar, um de seus grandes amigos e discípulos, Abhishiktânanda foi "um dos espíritos 'ocidentais' mais autênticos que aportaram em nossas costas para se expor à verdadeira experiência 'indiana' "2. Os estudiosos do diálogo inter-religioso sublinham, com acerto, que "a realidade da auto-exposição ao outro é condição para o diálogo autêntico em nossos dias $^{\prime \prime}$.

Na trilha aberta por místicos cristãos como Eckhart, Ruysbroek e Suso, o swâmî beneditino foi envolvido pelo mistério da interioridade. $\mathrm{O}$ acesso à dimensão de profundidade foi favorecido pela sedução da Índia, que preencheu todas as dimensões de seu ser, abrindo portas e janelas para uma experiência inusitada de um despertar religioso para além dos nomes e formas tradicionais. Foi alguém que não recusou viver a provocação dos grandes abismos e dos limites extremos, com todos os perigos que uma tal aventura comporta. Dizia em seu diário que tais vocações são necessárias e trazem consigo a força do Espírito. São pessoas que suscitam a explosão dos signos, pois são animadas por mirada mais ampla de um Real que é novidadeiro e fulminante ${ }^{4}$. O que faz de Henri le Saux um personagem instigante é o fato de ele não ter em momento algum largado suas convicções cristãs. Dentre os inúmeros ocidentais que viveram a experiência de uma conversão profunda, seja ao hinduísmo ou ao budismo, Abhishiktânanda foi um dos poucos que não romperam com suas precedentes convicções. Como um autêntico contemplativo, demonstrou

${ }^{1}$ M.M. DAVY, Henri le Saux. Le passeur entre deux rives, Paris: Albin Michel, 1997.

${ }^{2}$ R. PANIKKAR, "Lettera ad Abhishiktânanda", in H. LE SAUX et al., Alle sorgenti del Gange, Milano: Cens, 1994, p. 108.

${ }^{3}$ D. TRACY, A imaginação analógica. A teologia cristã e a cultura do pluralismo, São Leopoldo: Editora Unisinos, 2004, p. 562.

${ }^{4}$ H. LE SAUX, Diario spirituale di un monaco cristiano-samnyâsin hindû, Milano: Mondadori, 2001, pp. 356-357. 
com sua vida que só aquele que consegue assimilar de forma autêntica sua tradição é capaz dar um salto mais arrojado no enigma da alteridade ${ }^{5}$.

Foi também um grande precursor e pioneiro do diálogo inter-religioso. $\mathrm{O}$ início de sua experiência na Índia precede 15 anos ao evento do Concílio Vaticano II (1962-1965), ganhando, assim, contornos singulares e de vanguarda no processo de abertura dialogal que será deslanchado posteriormente. O clima do período, como indica Jacques Dupuis, era ainda muito reticente na questão do diálogo com outras tradições religiosas. Não havia, na ocasião, nenhum movimento litúrgico na Índia, e nem se pensava na possibilidade de adaptação da liturgia cristã à cultura do país. Os residuais esforços dialogais concentravam-se na esfera intelectual, sem repercussão positiva no âmbito da experiência religiosa ${ }^{6}$.

\section{Etapas de um itinerário dialogal}

Henri le Saux nasceu em Saint-Briac, um pequeno vilarejo na costa norte da Bretanha (França), em 1910. O seu nascimento foi um evento importante na vida de Alfred e Louise, seus pais, que o aguardavam há cinco anos. Permaneceu filho único por mais sete anos, até a chegada da irmã Louise e dos outros cinco irmãos que vieram para alegrar o círculo familiar. Tornou-se um exemplo para todos. Sua biógrafa, Shirley du Boulay, assinala que ele sempre permaneceu francês, mesmo depois de toda a sua imersão na Índia. Nunca abandonou a Bretanha, com seu imenso mar, e suas águas permaneceram tatuadas em seu coração ${ }^{7}$.

Já na infância esteve motivado pela vida sacerdotal. Sob o incentivo de seus pais, foi encaminhado ao seminário menor de Châteaugiron, no sudeste de Rennes, depois de seguir a primeira formação na escola local. Sua permanência nesse seminário se estenderá de 1921 a 1926, quando passa a freqüentar o grande seminário de Rennes, aos 16 anos. A vocação monástica nasce da amizade nutrida no seminário com um rapaz que manifestara o desejo de tornar-se beneditino, mas cuja morte prematura interrompeu o sonho almejado. Henri herda a vocação monástica do amigo, e entra no mosteiro beneditino de Kergonan, em

\footnotetext{
${ }^{5}$ Ibid, p. 15 (Prefácio de Panikkar); R. PANIKKAR, "Lettera ad Abhishiktânanda", p. 109.

${ }^{6}$ J. DUPUIS, Gesù Cristo incontro alle religioni, Assisi: Cittadella Editrice, 1991, p. 93.

${ }^{7}$ S. DU BOULAY, La grotte du coeur. La vie de Swami Abhishiktânanda (Henri le Saux), Paris: Cerf, 2007, pp. 27 e 33-34.
} 
outubro de $1929^{8}$. A grande paixão pelo silêncio vem ali alimentada e reforçada, bem como o amor pela liturgia e pela leitura dos Padres gregos e Padres do deserto. Henri le Saux vai ocupar por 12 anos a função de bibliotecário de Kergonan. A profissão solene é feita em maio de 1935. Alguns dos biógrafos do místico beneditino confirmam que Kergonan favoreceu um importante background para o desdobramento de sua vocação. Durante sua presença no mosteiro nasce uma de suas amizades mais sólidas, com Joseph Lemarié, que chega à abadia em 1936. Firma-se entre os dois uma relação de profunda confiança, que será testemunhada na longa correspondência que dura até o final de sua vida9 .

O apelo da Índia nasce, provavelmente, em 1934, nos primeiros anos de sua estadia em Kergonan ${ }^{10}$. Mas há ainda muito mistério em torno dessa questão, pois Le Saux foi sempre muito reservado a respeito. São raras as manifestações de sua insatisfação quanto às possibilidades de o mosteiro realizar plenamente suas aspirações mais profundas ${ }^{11}$. Nem o amigo mais próximo, o padre Lemarié, tomou ciência desse apelo antes de $1946^{12}$. Por dez anos o místico beneditino guardou silêncio sobre sua paixão pela Índia. A difícil decisão precisou ser longamente amadurecida, sendo revelada à irmã em 1944, seis meses após a morte da mãe. As difíceis negociações em torno da acolhida de seu projeto ganham luz em 1947, com a resposta positiva de uma carta enviada ao bispo Mendonça, de Tiruchirappalli. A mediação entre o bispo Mendonça e Le Saux foi realizada pelo padre Jules Monchanin ${ }^{13}$, que traduziu para o bispo a carta escrita em francês. Monchanin logo se identifica com a carta de Le Saux, reconhecendo ali uma resposta ao seu mais profundo desejo de assumir um novo projeto de vida na Índia. A resposta a Le Saux segue no mesmo ano, no início de agosto, onde assinala que a carta enviada ao bispo Mendonça chega como uma "resposta de Deus". Indica ainda que o seu verdadeiro

\footnotetext{
${ }^{8}$ A abadia Sainte Anne de Kergonan, na costa sul da Bretanha, foi fundada em 1010. O seu funcionamento foi interrompido por certo tempo no final do século XVII em razão do anticlericalismo francês, mas retoma fôlego no século XIX com a presença de dom Prosper Guéranger: S. DU BOULAY, La grotte du coeur, p. 51.

${ }^{9}$ H. LE SAUX, Lettres d'un sannyâsî chrétien à Joseph Lemarié, Paris: Cerf, 1999. Ver a propósito: J. STUART, Le bénédictin et le grand éveil, Paris: J. Maisonneuve, 1999, p. 61.

${ }^{10} \mathrm{Du}$ Boulay indica que o desejo de ir à Índia acompanhou Le Saux desde o ano de 1934, antes mesmo de sua ordenação: S. DU BOULAY, La grotte du coeur, pp. 84 e 87.

${ }^{11}$ J. STUART, Le bénédictin et le grand éveil, p. 24.

12 S. DU BOULAY, La grotte du coeur, p. 85.

${ }^{13} \mathrm{O}$ padre Jules Monchanin (1895-1957) tinha se ordenado em Lyon, em 1922, e partido para a Índia em 1939, para atuar pastoralmente junto aos tâmiles na diocese de Tiruchirapalli. Era um nome bem conhecido, "não somente por suas brilhantes qualidades intelectuais e a amplitude de seu campo de interesses, mas também por sua profundidade espiritual e sua maravilhosa capacidade de simpatia e amizade com as pessoas dos mais diversos meios": J. STUART, Le bénédictin et le grand éveil, p. 25.
} 
desejo não era o de seguir a vida missionária ordinária, mas o "caminho contemplativo sob a forma indiana"14. A vinda de um novo companheiro para o projeto vinha a calhar. Em entusiasmada carta de resposta a Monchanin, no mesmo mês, Le Saux fala de seu sonho guardado no coração por mais de 13 anos e da força do apelo da Índia. Expressa sua vontade de "desenvolver uma adaptação bem hindu da vida oblata beneditina e da hospitalidade beneditina, sob a forma de ashram, seja a pagãos ou cristãos que venham buscar alimento para a sua vida espiritual"15. De acordo com a tradição hindu, o termo sânscrito ashram indica o lugar onde habita um "homem santo", que dedica sua vida à busca de Deus, na solidão, silêncio, pobreza e abstinência. É o lugar por excelência dos "renunciantes" (sannyâsin).

A biógrafa Shirley du Boulay fala sobre o traço pioneiro da reflexão de Le Saux, numa época onde o cristianismo permanecia fechado aos apelos do tempo e deslocado da provocação inter-religiosa. A carta de Le Saux a Monchanin, com data de 18 de agosto de 1947, revela um conteúdo antecipador das mudanças que entrarão em cena no pensamento da igreja católica por ocasião do Concílio Vaticano $\mathrm{II}^{16}$.

Com a autorização de seu abade de Kergonan, Le Saux desembarca em terra indiana no dia 15 de agosto de 1948. A data marca um ponto de mudança decisiva na vida do monge de Kergonan. Ele não mais retornará à França, assumindo em 1960 a cidadania indiana. O processo de iniciação hindu começa desde cedo, quando Le Saux e Monchanin unem as forças para erguer em 1950 o saccidânanda ${ }^{17}$ ashram, que ficou mais conhecido como Shantivanam (a floresta da paz). A dinâmica de inserção no novo país implicou um amplo processo de aprendizagem dos hábitos, costumes e religiosidade indianos. Henri le Saux busca logo adotar o estilo de vida indiano e dedica-se com afinco ao estudo do sânscrito, do tâmil e das Escrituras hindus. Poucas semanas depois de sua chegada, busca os primeiros contatos com os ashrams hindus. Visita junto com Monchanin o ashram Ramakrishna e também o ashram de Ramana Maharshi, em Tiruvannâmalai, aos pés da montanha sagrada de Arunâchala ${ }^{18}$.

\footnotetext{
${ }^{14}$ J. MONCHANIN, Lettres au Père Le Saux, Paris: Cerf, 1995, p. 31 (carta de 07 de agosto de 1947).

${ }^{15}$ Ibid., pp. 33-41, aqui p. 37.

${ }^{16}$ S. DU BOULAY, La grotte du coeur, p. 100.

${ }_{17}$ A expressão saccidânanda significa: Sat (ser), cit (pensamento/inteligência), ananda (alegria perfeita).

${ }^{18}$ Esta montanha, dedicada à Shiva (que é fogo e flama), fica situada a 150 quilômetros ao sudesde de Madras, dominando a cidade de Tiruvannamalai. Em seu diário, Henri le Saux reverencia sua condição sagrada: "Ela é Shiva mesma sob forma de linga, o lugar mais santo do mundo": H. LE SAUX, Diario spirituale..., p. 52.
} 
O encontro de Henri le Saux com Ramana Maharshi, em 1949, foi de influência decisiva em todo o seu processo de transformação interior. Foi um breve contato, mas de intensidade kairológica. Em imagem registrada em seu diário ${ }^{19}$, Le Saux fala do inesquecível "sorriso pleno de bondade" do mestre hindu ${ }^{20}$. Mas não pôde aproveitar toda a riqueza do encontro, pois era ainda "muito noviço na ciência da interioridade". Não só desconhecia a língua tâmil, como estava ainda muito apegado aos condicionamentos de sua formação pregressa: da hereditariedade cristã, da linguagem, dos hábitos, dos "nós do coração" e dos vínculos que o atavam à dinâmica exclusivamente cristã.

É com Ramana Maharshi (1879-1950) que se dá a verdadeira iniciação de Henri le Saux à espiritualidade hindu. Trata-se de um dos maiores mestres espirituais da Índia moderna, por muitos considerado um homem santo e encarnação de Shiva ${ }^{21}$. Sua vida espiritual esteve sempre ligada à montanha sagrada de Arunâchala, onde encontrou sua realização pessoal. $\mathrm{O}$ amor pela montanha foi fulminante, desde o primeiro encontro em 1896, quando sai de casa, aos 17 anos, movido por um apelo a que não conseguiu resistir. Permanece junto à montanha sagrada até sua morte, em 1950. Ali ficou solitário e em silêncio por muitos anos, entre as grutas de Arunâchala, até que em certo momento resolveu aceitar discípulos e ao seu redor nasceu o ashram de Tiruvannamalai, aos pés de Arunâchala. Entre as características deste grande místico, está a força e o potencial de sua experiência da não-dualidade (advaita). É alguém que fala muito mais pela sua presença e pela "imperiosa fascinação". Em obra sobre Arunâchala, recorda Le Saux: "As palavras eram o que havia de menos importante entre os meios pelos quais o Sábio transmitia a sua experiência"22. Não deixou livro pessoal publicado. O que existe são registros feitos por seus discípulos das respostas dadas pelo mestre na dinâmica de sua formação ${ }^{23}$.

\footnotetext{
19 O diário de Henri le Saux começou a ser escrito no final de 1948, mas não havia a intenção de ser publicado. Para Panikkar, autor do prefácio, o diário oferece "um exemplo fascinante da evolução de um pensamento". O livro foi publicado por decisão de um grupo de amigos de Le Saux, e o titulo original escolhido foi: La montée au fond du coeur (a subida ao fundo do coração), com base em reflexão feita pelo próprio Abhishiktânanda em seu grande retiro silencioso de 1956: H. LE SAUX, Diario spirituale..., pp. 14 e 20.

${ }^{20}$ H. LE SAUX, Diario spirituale..., pp. 52-56.

${ }^{21} \mathrm{Um}$ dos grandes deuses do hinduísmo, identificado com o símbolo fálico linga, e modelo dos ascetas e yogues.

${ }^{22}$ H. LE SAUX, Ricordi di Arunâchala, Padova: Messaggero Padova, 2004, p. 59.

${ }^{23}$ A respeito de Ramana ver: P. BRUNTON, A Índia secreta, São Paulo: Pensamento, 1996, pp. 125-152; D. GODMAN (org.), Sii ciò che sei. Ramana Maharshi e il suo insegnamento, Vicenza: Il Punto d'Incontro, 2007; L'INSEGNAMENTO spirituale di Ramana Maharshi, Roma: Mediterranee, 1992.
} 
Além do primeiro encontro com Ramana, no início de sua jornada na Índia, Le Saux encontrou-se novamente com o mestre indiano seis meses depois, em agosto de 1949, mas ele já estava bem doente. Já mais preparado espiritualmente, Le Saux buscou neste novo encontro romper com as barreiras racionalistas para beber a gratuidade de seu "influxo secreto" 24 . Nessa sua nova visita ao ashram de Tiruvannamalai, tomou também consciência de que o lugar guardava não apenas um mestre, Ramana, mas também uma montanha sagrada, Arunâchala ${ }^{25}$. Tomou-se de encanto pelos dois. Na verdade, Le Saux "tinha vindo à Índia para fundar um ashram, mas em lugar disso, encontrou Ramana Maharshi e Arunâchala"26. Com o mestre Ramana, Le Saux viveu a experiência de uma "comunhão misteriosa" e a iniciação no mais puro advaita. É um encontro que marca uma virada decisiva em sua vida. Em página de seu diário, em novembro de 1956, Le Saux reafirma o vínculo essencial que estabeleceu com o guru e a montanha:

Se para retornar cristão tivesse que deixar-te, oh Arunâchala, tivesse que abandonar-te, oh Ramana, então não poderia mais retornar cristão, pois entraram na minha carne e estão ligados nas fibras de meu coração ${ }^{27}$.

A inauguração do ashram de Shantivanam aconteceu em março de 1950, por ocasião da festa de são Bento. Seguindo a tradição indiana, Henri le Saux e Monchanin receberam novos nomes. O primeiro foi nomeado como Abhishikteshvarânanda (aquele cuja alegria é a unção do Senhor), reduzido posteriormente para Abhishiktânanda. O segundo recebeu o nome de Parama Arûbi Ananda (aquele cuja alegria é o Supremo sem-forma). Os dois passam a adotar a veste tradicional hindu, de cor açafrão, dos samnyâsin (ascetas renunciantes). Como marca da nova vida, adotam a cruz de são Bento marcada em seu centro com o símbolo sagrado "Om"28. Na visão de Le Saux e Monchanin, na ocasião, esse mantra seria "mais apto que nenhum outro a uma reinterpretação cristã". Um símbolo "audível e pronunciável, mais etéreo, mais despojado, último esteio do 'verbo' humano em sua ascensão para o Absoluto e, por isso, particularmente apto a exprimir, evocar pelo menos, o inexprimível kevala, Deus em sua Solidão, em sua Aseidade, em sua Deidade" ${ }^{29}$.

${ }^{24}$ H. LE SAUX, Ricordi di Arunâchala, pp. 70-71.

${ }^{25}$ Como sublinhou Sonia Calza, Ramana não era senão "um dos rostos de Arunâchala": S. CALZA, La contemplazione, Via privilegiata al dialogo cristiano-induista, Milano: Paoline, 2001, p. 103.

${ }^{26}$ S. DU BOULAY, La grotte du coeur, p. 170.

${ }^{27}$ H. LE SAUX, Diario spirituale..., p. 249.

${ }_{28}$ Trata-se de um mantra védico que simboliza o inefável mistério de Deus.

${ }^{29}$ J. MONCHANIN / H. LE SAUX, Eremitas do Saccidânanda, Belo Horizonte: Itatiaia, 1959, p. 205. 
Para os dois fundadores de Shantivanam, o ashram vinha responder a um desejo bem definido: "nada mais do que estar em presença de Deus". Abhishiktânanda permaneceu ali por 25 anos, e o novo espaço fornecia a ele a necessária credibilidade aos olhos dos amigos e da hierarquia católica. Mas nunca esteve plenamente à vontade nesse ashram, e o seu malestar com a fundação vai se ampliando ao longo do tempo, na medida em que aprofundava o seu mergulho no hinduísmo. Um mergulho que vai provocar crescente inquietação em Monchanin ${ }^{30}$.

A grande paixão de Abhishiktânanda estava, porém, mais além, escondida na montanha sagrada de Arunâchala. Passa longos períodos nas grutas da montanha entre os anos de 1952 e 1953. Aprofunda ali sua reflexão sobre a nova identidade a ser assumida e vislumbra novos caminhos de inserção religiosa. O apelo da experiência do advaita começa a tocar mais forte o seu coração. A montanha sagrada começa a revelar para ele sua tônica sedutora, e ali experimenta um verdadeiro "banho de silêncio". Em magnífico poema de abril de 1952, descreve como foi capturado por Arunâchala:

\section{Oh Arunâchala}

Shiva, o benévolo e generoso

Santa, o pacífico,

Advaita, o Um-sem-segundo,

Pûrna, plenitude

Ananda, bem-aventurança.

Tu não terás paz senão quando também me levares aos teus pés de loto,

e me fizeres penetrar na caverna de teu coração. (...)

Consuma-me, queima em mim tudo o que não é Tu.

Oh coluna de fogo, Oh coluna de Amor.

Oh Tejo linga, Oh esperma de fogo.

Que de teu Fogo eu renasça Tu. (...)

O teu sussurro há tempos me chamava,

os mares me fizeste atravessar,

e, tendo entrado em Teu seio, senti uma paz

que jamais havia provado,

paz, plenitude, alegria,

shânti, pûrna, ânanda (... $)^{31}$.

Sobre o apelo de Arunâchala volta a falar em novembro de 1956, com uma interrogação precisa feita ao mistério que o convocou:

\footnotetext{
${ }^{30}$ J. MONCHANIN, Lettres au Père Le Saux, pp. 215 e 149.

${ }^{31}$ H. LE SAUX, Diario spirituale..., pp. 89-90.
} 
Se verdadeiramente é a Igreja que tem palavras de vida eterna, e é a única que as possui, por que então, oh meu Deus, me conduziste a Arunâchala e brincaste comigo abrindo no fundo do meu coração as cavernas de Arunâchala? (...) Agora tenho medo, tenho medo, um oceano de angústia para onde quer que me mova. Tu me chamas sob o nome de Arunâchala, e como resistir aos teus braços que me apertam, aos teus lábios que se colam ao meu? Mas se fosse apenas um jogo Teu, porque a Igreja me grita que não és Tu esta forma? Tenho medo, veja, de renegar, permanecendo ligado à Igreja, este mistério interior onde não há mais nem Tu nem Eu, e que Tu me revelaste em Arunâchala (...). Contudo não, Tu não és uma miragem, oh Arunâchala. Tu és a montanha que é feita de granito sólido e que não vacila, acala. És a aurora, arunâ, que se levantou inflamada ao cume do meu coração, não é irreal ${ }^{32}$.

A experiência de Arunâchala significou para Abhishiktânanda o desafio de penetrar em âmbitos de maior profundidade da experiência espiritual. Confidencia a respeito em carta a seu amigo Lemarié, datada de 29 de abril de 1953: "Cada vez que se crê tocar o fundo; e à medida que se desce ao fundo, descobrem-se círculos cada vez mais profundos de profundida$\mathrm{de}^{\prime \prime 33}$. Com a inspiração de Ramana e Arunâchala, Abhishiktânanda começa a redigir em 1952 e 1953 os textos que vão compor um de seus livros mais polêmicos, Guhântara ${ }^{34}$. Tratava-se de um primeiro confronto do cristianismo com a experiência do advaita. A reação de Monchanin ao ler o texto de Abhishiktânanda, em carta ao amigo Duperray, é de estupefação: "O interior da caverna emudeceu-me profundamente. Creio que ninguém ainda tinha ido tão longe na percepção espiritual do hinduísmo"35. Não deixa, porém, de fazer reservas ao livro ${ }^{36}$. Outras criticas vieram se somar ao posicionamento de Monchanin: do censor eclesiástico de Paris e do Pe. Bayard. Mas recebe, curiosamente, a aprovação de Henri de Lubac. Abhishiktânanda conclui que a igreja não estava ainda preparada para a recepção da obra e que "só os contemplativos a poderiam compreender"37. O livro acabou não sendo publicado durante a vida de Abhishiktânanda. Após sua morte, parte da obra foi publicada em dois volumes: Iniciação à espiritualidade dos Upanishad (1979) e Interioridade e revelação (1982) ${ }^{38}$.

\footnotetext{
32 Ibid., p. 254. Em página do mesmo diário, em abril de 1964 dirá: "É necessário viver sobre a montanha o parto da Igreja, a passagem do confortável ventre materno ao dia pleno do Real (...)".Ver ainda: ID., Ricordi di Arunâchala, pp. 85-195.

${ }^{33}$ H. LE SAUX, Lettres d'un sannyâsî chrétien..., p. 70.

${ }^{34}$ Cuja tradução poderia ser: "entrada no interior da caverna".

${ }^{35}$ J. MONCHANIN, Lettres au Père Le Saux, p. 128.

${ }^{36}$ Ibid., p. 213.

${ }^{37}$ J. STUART, Le bénédictin et le grand éveil, pp. 83-86, aqui p. 86.

${ }^{38}$ H. LE SAUX, Iniciation à la spiritualité des Upanishad, Paris: Présence, 1979; ID., Intériorité et révélation: essais théologiques, Sisteron: Présence, 1982.
} 
Outro mestre da tradição indiana com o qual Abhishiktânanda desenvolveu sua experiência espiritual foi Srî Gnânânanda ${ }^{39}$, do Taponavam ashram, em Tirukoyilur, em dezembro de 1955, na primavera de 1956 e março de 1957. Foi um importante yogue que deslanchou o processo de interiorização de Abhishiktânanda, e com o qual viveu uma importante relação de discipulado. Sobre esse mestre indiano, que faleceu em 1974, Le Saux publicou um livro em $1970^{40}$. Sobre o encontro de 15 dias com o guru indiano, comentou em carta de março de 1956 para o amigo Lemarié: "Nele senti a verdade do advaita... Ele gostaria que eu pudesse consagrar todo o meu tempo vindouro à meditação sem pensamentos, deixando tudo de lado, não somente as distrações e conversações inúteis, mas igualmente toda leitura"41. Na tradição hindu costuma-se dizer que quando o discípulo está pronto o guru logo se apresenta. O sábio Gnânânanda foi alguém que entrou no caminho de Abhishiktânanda para manter acesa em sua mente a atenção para a profundidade do coração. O guru é aquele que "viveu a experiência do Espírito, da Realidade suprema e conhece em primeira pessoa o caminho que a tal experiência conduz" ${ }^{\prime \prime 2}$. É alguém que fala diretamente ao coração, sendo capaz de iniciar o discípulo no caminho espiritual a partir do núcleo mesmo de sua profundidade, e partilhar com ele a inefável experiência que viveu em âmbito pessoal. O guru é simplesmente "um iniciador; sua única tarefa é tornar a alma disponível para o Espírito" ${ }^{\prime 3}$.

Em sua rica trajetória espiritual, Abhishiktânanda estabeleceu importantes laços de amizade. Vale destacar a relação de proximidade que manteve até o final da vida com Raimon Panikkar, outro grande buscador do diálogo. Como assinala Shirley Du Boulay, "era a única pessoa com a qual podia partilhar plenamente suas idéias", estando em plena sintonia intelectual ${ }^{44}$. Panikkar esteve ao lado de Abhishiktânanda em momentos decisivos de sua vida, com sua presença e apoio, como na difícil decisão de deixar Shantivanam, na defesa da obra Guhântara, na decisão de avançar na experiência de interioridade hindu etc. Os dois sempre estiveram muito próximos, numa relação de escuta mútua e aprendizado permanente ${ }^{45}$. Fizeram juntos uma rica peregrinação espiritual, nas fontes do rio Ganges,

\footnotetext{
${ }^{39}$ Não há muitas informações sobre a infância e juventude de Srî Gnânânanda. Especulase que seu nascimento ocorreu na primeira metade do século XIX num vilarejo próximo a Mangalore. Passou muitos anos como asceta no Himalaya, tendo em seguida uma vida itinerante. Teve contatos com Srî Aurobindo e Ramana Maharshi. Estabeleceu-se finalmente em Tirukoyilur (Tamil).

${ }^{40}$ H. LE SAUX, Gnânânanda, un maître spirituel du pays tamoul, Paris: Présence, 1970.

${ }^{41}$ H. LE SAUX, Lettres d'un sannyâsî chrétien..., p. 145.

${ }^{42} \mathrm{C}$. CONIO, Abhishiktânanda sulle frontiere dell incontro cristiano-indù, Assisi: Cittadella Editrice, 1994, p. 45.

${ }^{43}$ H. LE SAUX, Risveglio a sé risveglio a Dio, Sotto il Monte: Servitium, 1996, p. 112.

${ }^{44}$ S. DU BOULAY, La grotte du coeur, p. 260.

${ }^{45}$ H. LE SAUX, Lettres d'un sannyâsî chrétien..., pp. 216 e 310.
} 
que está registrada em publicação específica ${ }^{46}$. Panikkar escreveu o prefácio do diário espiritual de Abhishiktânanda, e foi quem deu o belo título de sua edição original: "La montée au fond du coeur". Escreveu também uma linda carta ao amigo Svâmijî, depois de sua morte, que é também um referencial para o conhecimento de seu itinerário interior ${ }^{47}$.

A grande crise espiritual vivida por Abhishiktânanda nos anos de 1955 e 1956 vai sendo aos poucos apaziguada, na medida em que aprofunda sua vida interior em contato com a grande tradição hindu, e em particular com os Upanixades. Com o avançar dos anos, o ritmo de simplicidade e gratuidade vai envolvendo todo o seu ser, de forma a favorecer uma serenidade singular. A meta essencial de sua vida vai também ganhando uma clareza única: de união profunda com Deus e os irmãos. Firma-se em sua consciência a idéia de que a revelação cristã e a experiência hindu podem ser reconciliadas em nível de profundidade, sem com isso romper os traços distintos e irredutíveis que as separam.

Em novembro de 1955, Abhishiktânanda confidencia ao seu amigo Lemarié que a experiência de Arunâchala deixou marcas de grande profundidade em sua vida. Sua aspiração mais arraigada era mesmo a solidão. Vai amadurecendo nele a decisão de deixar Shantivanam para dedicar-se mais a fundo à vida eremítica. Mas isso só vai ocorrer em 1968, quando a responsabilidade do ashram passa a ser assumida por Bede Griffiths e Francis Mahieu. Em 1959 faz sua primeira viagem aos Himalayas, e fica fascinado pela beleza do lugar. É o início de seu itinerário para o norte, que foi favorecido pela amizade do reverendo Murray Rogers e seu grupo anglicano, bem como Raimon Panikkar.

A experiência mais estrita de vida eremítica começa em 1968, mas vai ser um eremita sempre muito ativo. Dizia que "a contemplação é (...) permanecer na Presença sem deixar de estar presente a cada um e cada uma das coisas $^{\prime \prime 4}$. Sem perder sua dinâmica itinerante, passa a viver como eremita em Gyansu, nas margens do rio Ganges. Chega o momento de uma vida mais reservada, depois de um longo período de vida comunitária, ainda que elástica. Não deixa, porém, de participar de uma série de atividades relacionadas ao Christa Prema Seva Ashram de Pona, um núcleo empenhado no diálogo cristão-hindu ${ }^{49}$.

\footnotetext{
${ }^{46}$ H. LE SAUX et al., Alle sorgenti del Gange.

${ }^{47}$ Svâmijî era a forma carinhosa como Panikkar tratava o amigo Abhishiktânanda. É um termo que deriva de Svâmi, cujo significado é Senhor, mestre. Trata-se de um título de samnyâsin (renunciante). A mencionada carta de Panikkar foi publicada no livro: H. LE SAUX et al., Alle sorgenti del Gange, pp.105-152. E dá continuidade à carta, trinta anos depois, no prefácio do já citado livro de Shirley du Boulay, La grotte du coeur, pp. 11-16. ${ }^{48}$ S. DU BOULAY, La grotte du coeur, p. 277.

${ }^{49}$ S. CALZA, La contemplazione..., p. 89.
} 
Nesse período dedica-se também à orientação espiritual de dois discípulos franceses: a irmã Thérèse, proveniente do Carmelo de Lisieux ${ }^{50}$, e o jovem seminarista de Bourg en Bresse, Marc Chaduc, com o qual vai estabelecer um profundo intercâmbio desde maio de $1969^{51}$. Os dois discípulos chegam à Índia em 1971. Abhishiktânanda vê em Marc uma vocação muito especial e com ele estabelece uma íntima relação de guru e discípulo ${ }^{52}$. Marc revelava ser alguém de uma excepcional profundidade espiritual, e as cartas enviadas por Abhishiktânanda ao discípulo são testemunhas dessa qualidade singular. $\mathrm{O}$ encontro com Marc Chaduc, em especial, suscita nova reviravolta na vida de seu guru. Era tal o nível de profundidade entre os dois que Abhishiktânanda chegou a pensar num movimento de mudança mais radical em sua vida, como relatou a seu amigo Lemarié: "Se tivesse força psíquica, eu me libertaria ainda mais rápido de todos os meus engajamentos, como Marc, e partiria para outras veredas ou pelo menos para a floresta às margens do Ganges, sem sequer um livro, senão os Upanixades e o Novo Testamento" 53 . Com Marc, Abhishiktânanda decide aprofundar o seu contato e estudo dos Upanixades. Os dois passam três semanas dedicadas integralmente ao seu estudo, em 1972, no ashram de Phulchatti. Foi um período de grande inspiração, do qual nasceram as bases para a redação de um longo ensaio de Abhishiktânanda de introdução aos Upanixades. Em cartas a amigos, em 1972, sublinha a importância e o significado do estudo feito com Marc sobre o tema. Assinala, entre outras coisas, a "mutação" provocada pela experiência: a "impressão indelével" deixada e a inspiração para fundamentais mudanças a serem realizadas na igreja e nas outras religiões ${ }^{54}$.

Em junho de 1973, o discípulo Marc recebe a iniciação (dîkshâ) de sannyâsin, nas margens do rio Ganges. Numa cerimônia simples e bela, o discípulo recebe do próprio mestre sua iniciação, recebendo o novo nome: Ajâtânanda (bem-aventurança do não nascido). Segundo Panikkar, o amigo Svâmîîî encontrou em Marc o discípulo que buscava, e com ele, a experiência da "plenitude humana da paternidade" 55 . Em julho do mesmo ano, mestre e discípulo passam juntos três dias de intensa vida espiritual, no pequeno templo de Ranagal, nas proximidades do Ganges ${ }^{56}$. Em carta dirigida à sua

\footnotetext{
${ }^{50}$ Henri le Saux já se correspondia com a irmã Thérèse desde 1959. Ela chega à Índia, para a experiência eremítica em novembro de 1971.

${ }^{51}$ O biógrafo James Stuart fala ainda de dois outros discípulos hindus de Abhisiktânanda: Ramessh e Lalit: J. STUART, Le bénédictin et le grand éveil, p. 262.

${ }^{52}$ James Stuart sublinha que este tipo de relação guru-discípulo "não tem paralelo na cultura ocidental", sendo difícil para os ocidentais sua compreensão, que é muitas vezes deturpada: J. STUART, Le bénédictin et le grand éveil, p. 261.

${ }^{53}$ H. LE SAUX, Lettres d'un sannyâsî chrétien..., p. 417.

${ }^{54}$ J. STUART, Le bénédictin et le grand éveil, p. 279.

${ }^{55}$ H. LE SAUX, Diario spirituale..., p. 30 (Prefazione).

${ }^{56}$ Outras experiências espirituais entre os dois tinham acontecido antes, como em novembro de 1971 (em caminhada com Marc junto ao Ganges, perto do ashram de Phûlchatti),
} 
irmã, Maria-Thérèse Le Saux, em agosto de 1973, Abhishiktânanda assinala que a experiência interior foi tão forte que o corpo teve dificuldade de suportá-la $a^{57}$. O mestre reconhece que o discípulo realizou plenamente o ideal do sannyâsa, dando um passo ainda mais radical: "Aquele que estava atrás de mim, passou adiante, e eu não posso mais atingi-lo..." ${ }^{\prime 58}$. Os dois participam, porém, da vida que procede de uma mesma profundidade. Poucos dias depois, em 14 de julho, Abhishiktânanda sofre um infarto do miocárdio. Os primeiros dias que se seguiram ao ataque cardíaco foram, paradoxalmente, de grande iluminação e felicidade para Svâmîjî. Em seu diário íntimo relata a "maravilhosa aventura espiritual" da grande semana que vai do dia 10 a 18 de julho. Ele sublinha:

Depois de alguns dias me vem, por assim dizer, a solução maravilhosa de uma equação: descobri o Graal. E isto digo e escrevo a quem quer que seja capaz de aferrar a imagem. A busca do Graal não é senão a busca de Si. (...) E nesta busca corre-se para todo lado, enquanto o Graal está aqui, bem próximo, basta abrir os olhos ${ }^{59}$.

Para alguém que já havia atravessado a "morte" do esvaziamento de si, não foi difícil afrontar a "pequena morte", ocorrida no dia 07 de dezembro de 1973. Os grandes místicos, das mais diversas tradições, afirmam que a tarefa mais árida e complexa é "morrer antes de morrer".

\section{Entre dois amores}

Em toda a sua trajetória de vida na Índia, Abhishiktânanda partilhou a presença de dois amores: o cristianismo e o hinduísmo. Conseguiu trilhar o seu caminho participando intensamente destes dois "mundos", sobretudo em razão de um chamado que sempre foi muito mais forte em sua vida: o apelo do Real. Foi um buscador singular, que não se poupou a disponibilizar-se para viver o desafio de duas grande tradições religiosas,

na festa de ascensão em maio de 1972, no Shivananda ashram (Rishikesh), e na experiência conhecida como o "Upanixades de fogo", ainda no mês de maio, no terraço do mesmo ashram. A propósito ver: H. LE SAUX, Diario spirituale..., pp. 443-448. Ver ainda: L. VALERA, A ponte entre as duas margens. A experiência inter-religiosa de Henri le Saux, Dissertação de Mestrado, PPCIR, UFJF, 2007, pp. 95-98.

${ }^{57}$ H. LE SAUX, Ricordi di Arunâchala, p. 26. Ele diz em carta a outros amigos que a experiência de contato com os Upanixades quase o destruiu: "é todo o fundo da alma que se eleva, assim como as ondas do fundo oceânico elevam e agitam as águas do mar... É muito forte sentir a presença do Verdadeiro. É alguma coisa que queima...”: C. CONIO, Abhisiktânanda..., p. 81.

${ }^{58}$ H. LE SAUX, Diario spirituale..., p. 485.

${ }^{59}$ Ibid., p. 488. 
a duas espiritualidades distintas e complexas. Sua grande virtude foi ter conseguido manter sua fidelidade à tradição cristã, sem romper com a abertura ao mistério do advaita hindu.

Não foi porém uma aventura espiritual desprovida de tensão e angústia. O diário de Abhishiktânanda é permeado pela presença de uma "luta interior" lacerante, e que foi mais intensa entre os anos de 1953 a 1956. Trata-se do período em que viveu a experiência de Arunâchala, com seus desdobramentos espirituais. Ali encontrou algo mais, uma vida interior fascinante, desveladora da guha (gruta) do coração. A angústia de Abhishiktânanda estava justamente no delicado processo de manter o equilíbrio entre os dois amores, de não romper com nenhum dos vínculos que o domiciliavam no mistério maior. Em página de seu diário, em fevereiro de 1956, relata essa tensão:

A angústia essencial de não conseguir encontrar repouso e alegria em nada daquilo que sempre me deu alegria e repouso. No meu 'pensamento' de Deus e na minha 'relação' com Deus, qualquer que tenha sido... Porque lá onde quero ou me disponho a fixar-me, um neti, neti imperioso e sem misericórdia surge da profundidade de meu ser: não pare, não pare... $\mathrm{E}$ uma outra voz me diz: se não parar, corre para o abismo, para o abismo essencial $^{60}$.

A raiz de todo o sofrimento estava na tensão de querer conciliar o advaita com o cristianismo. Dizia que a fonte de toda sua angústia estava no querer "permanecer cristão". Acreditava que se tivesse a coragem de "dar um decisivo passo adiante para aceitar sinceramente o advaita com todas as suas possíveis conseqüências, incluindo a de 'deixar' o cristianismo, tudo leva a crer que estaria em paz" ${ }^{\prime 1}$. Mas não era essa a paz que ele queria, nem o movimento de vida que fez. Mesmo tendo encontrado no hinduísmo a alegria e a paz, como disse em vários momentos, o cristianismo pulsava forte em seu mundo interior: "há no fundo de mim um adhisthânanda (fundamento) cristão dificilmente eliminável" ${ }^{\prime \prime 2}$. O tormento de viver estas duas existências provoca nele um tal oceano de angústia que chega mesmo a pensar em morrer: "não posso mais viver aqui como monge cristão; e não posso mais viver como monge hindu. Que o Senhor tenha piedade de mim e tire a minha vida! Não mais resisto..."63.

O apelo do advaita $^{64}$ tem a ver, sobretudo, com o âmbito da experiência. Com o amadurecer do tempo, Abhishiktânanda vai percebendo que o

${ }^{60}$ Ibid., p. 214.

${ }^{61}$ Ibid., p. 263.

${ }^{62}$ Ibid., p. 243.

${ }^{63}$ Ibid., p. 218.

${ }^{64} \mathrm{O}$ termo advaita vem do sânscrito, e pode ser entendido como "não dualidade", ou ainda "a-dualidade". Envolve uma intuição de que a realidade não é nem monista nem dualista. 
encontro verdadeiro entre o cristianismo e o hinduísmo deve se operar no seu mundo interior, no nível da experiência. A espiritualidade advaita, como vem mostrando Panikkar, envolve uma dialógica da meta-noia, ou seja, um processo que rompe toda dualidade e escapa de uma inteligibilidade estritamente racional. Não se trata simplesmente de negar a dualidade, mas de não se deixar fixar-se na mesma:

A intuição advaita não consiste em afirmar a unidade ou negar a dualidade, mas precisamente, com uma visão que transcende o intelecto, saber reconhecer a ausência de dualidade na base de uma realidade que em si mesma carece de dualidade, que não pode ser expressa numericamente, uma vez que não há um dois ${ }^{65}$.

Não há como captar o significado do advaita senão através do "olho da fé", ou seja, de um terceiro olho que envolve a experiência da realidade (anubhâva). A tensão espiritual de Abhishiktânanda vai se arrefecendo na medida em que aprofunda a verdade advaita e sua dinâmica existencial, que tem proximidade maior com o shivaísmo. Mas a intuição que acompanha sua nova consciência implica um desafio de ir sempre além, de avançar com ousadia no âmbito da experiência, de um desnudamento cada vez mais radical visando a captação do Real. Nos últimos cinco anos de sua vida, Abhishiktânanda vive com intensidade esta experiência advaita, concebendo-a como algo fundamental para a integração do ser humano e sua relação com o contexto mais amplo. Para ele, a nova intuição revelava uma essencial importância para o mundo e para a igreja.

É interessante constatar como que na medida em que Abhishiktânanda descobre a intuição advaita ele rompe com sua anterior visão teológica, identificada com a teologia do acabamento, segundo a qual todas as demais tradições religiosas encontram no cristianismo o seu remate e realização. Antecipando uma importante discussão teológica que se dará no pósVaticano II, Svâmîjî assinala que a teologia do acabamento não consegue fazer justiça ao pluralismo religioso. Num artigo sobre a questão dos "arquétipos religiosos", escrito em 1970, mas só publicado após sua morte, levanta sugestivas reflexões sobre o pluralismo religioso como valor irrevogável ${ }^{66}$. Trata-se de uma reflexão pioneira para a teologia das religiões e que aborda os limites de uma teologia do acabamento. Como sublinhou James Stuart, em reflexão a propósito, "uma teologia do acabamento, não somente implica uma visão irrealista do futuro desenvolvimento da Igreja, mas, o que é mais importante, deve ser radicalmente modificada a

${ }^{65}$ R. PANIKKAR, Il dharma dell'induismo, Milano: BUR, 2006, p. 171.

${ }^{66} \mathrm{O}$ artigo, que trata o tema dos arquétipos religiosos, foi publicado no seguinte livro: H. LE SAUX, Intériorité et révélation, pp. 177-207. Sobre a defesa do pluralismo religioso, ver em especial as pp. 192-195 e 197-198. 
partir do momento em que o pluralismo religioso vem tomado a sério, como o que ocorreu com o Vaticano $\mathrm{II}^{\prime \prime 67}$.

Com o aprofundamento de sua imersão no advaita hindu, Abhishiktânanda vai tomando distância não só de sua experiência em Shantivanam, mas também de seu companheiro Monchanin. A diferença entre os dois amigos foi se evidenciando ao longo do tempo. Enquanto Monchanin não conseguia vislumbrar uma saída possível para o profundo abismo que, a seu ver, separava o hinduísmo do cristianismo, Abhishiktânanda via nesse abismo um desafio ainda maior para acreditar num encontro que deveria acontecer no âmbito da profundidade. O primeiro era essencialmente um pensador, enquanto o segundo, alguém seduzido pela experiência e decidido a levá-la adiante. Monchanin pressentia na ousadia do amigo o risco maior de uma perda de identidade. Ele se inquieta com o curso tomado pela vida do amigo. Sentia-se, de certa forma, responsável pelo companheiro que veio à Índia por sua interlocução. Para Abhishiktânanda, havia um obstáculo intelectual impedindo o parceiro de ir mais a fundo na experiência do vedanta. Ele o achava muito grego para tal alcance. E sofre com os questionamentos sofridos, tendo dificuldade de reagir ao amigo, com o qual se sente unido por laços de profundo apreço. Lamenta em seu diário: “É difícil combater aqueles que não vos amam. Mas contra aqueles que vos amam, que se opõem a vós por razões do dharma (religião)! Esta é a minha situação com padre Monchanin e com os meus amigos da Igre$\mathrm{ja}^{\prime \prime 68}$. É curioso observar que Monchanin, apesar do grande apreço que nutre pelo amigo bretão, busca restringir o seu vôo, reagindo aos toques de ousadia de sua reflexão. Isto vai ocorrer na sua resistência a certas passagens do livro feito em comum: "Eremitas do saccidânanda", sobre a conveniência da publicação do livro "Guhântara", bem como à dinâmica de envolvimento de Abhishiktânanda com o seu guru Gnânânanda ${ }^{69}$. São reações que expressam o temor de um mergulho mais fundo no mundo da alteridade.

O engajamento espiritual de Abhishiktânanda em dois mundos religiosos distintos, coloca a complexa questão de sua dupla pertença. Se mesmo hoje a questão é mal digerida, na década de 50 era ainda muito mais, podendo

\footnotetext{
${ }^{67}$ J. STUART, Le bénédictin et le grand éveil, p. 241. Ver ainda: S. DU BOULAY, La grotte du coeur, pp. 172-173 e 313.

${ }^{68}$ H. LE SAUX, Diario spirituale..., p. 281. Monchanin vai reagir permanentemente contra o desejo de Abhisiktânanda deixar Shantivanam. Ele o vai acusar de egoísmo e outras coisas mais. As resistências virão também de outros amigos como B. Griffits e F. Mahieu. Ver a respeito: S. DU BOULAY, La grotte du coeur, pp. 260-262, 167-168. E também: J. MONCHANIN, Lettres au Père Le Saux, pp. 114, 149, 243-244; J. STUART, Le bénédictin et le grand éveil, pp. 61 e 80.

${ }^{69}$ J. STUART, Le bénédictin et le grand éveil, p. 73; J. MONCHANIN, Lettres au Père Le Saux, p. 227; S. DU BOULAY, La grotte du coeur, p. 223.
} 
passar quase que por heresia naquele contexto da tradição cristã. Não é de se estranhar que a dupla pertença do buscador bretão vai deixá-lo meio isolado, mesmo entre os amigos mais próximos, como Monchanin. Um dos poucos que o apoiaram na época foi Panikkar, para o qual a lealdade de Abhishiktânanda a duas visões de mundo não implicava um problema ou contradição $\mathrm{O}^{70}$. O que estava em curso, e que não pode ser confinado numa racionalidade estreita, era a fidelidade de um buscador ao mistério do Real. Mais do que uma questão de idéias, estava em jogo um testemunho autêntico de vida.

Em âmbito da reflexão teológica contemporânea, Jacques Dupuis levanta a discussão sobre a plausibilidade de uma partilha de experiências de fé diferentes. Argumenta que, se de um ponto de vista absoluto é algo problemático, dado o caráter de envolvimento integral que cada fé religiosa implica, não se pode, por outro lado, excluir tal possibilidade, em razão de experiências significativas e positivas que confirmam a hipótese ${ }^{71}$. O teólogo Claude Geffré também admite a viabilidade de uma dupla pertença no âmbito da experiência religiosa. Considera legítimo e viável a assunção feita por cristãos de elementos "estranhos" à própria tradição, como fator de enriquecimento da própria religião. Ele não só reconhece essa possibilidade como nela desoculta traços que são "prometedores de novas figuras históricas do cristianismo"72. Em outro artigo sobre a questão, Geffré assinala a impossibilidade de admissão de uma dupla pertença quando se aborda a questão da "religião como sistema", mas no caso de tratar a religião como "experiência interior e como entrega total de si a um Absoluto" que ultrapassa o sujeito, considera possível afirmar uma "continuidade" $^{\prime \prime}$ entre experiências religiosas distintas ${ }^{73}$.

Não se pode brandir tais experiências como relativistas assim como se tende a fazer em determinadas situações, de forma superficial e dogmática. Há que avaliar seriamente cada caso, com espírito de abertura e acolhida. Aqueles que vivem uma semelhante experiência podem ser reconhecidos como "pessoas liminares", para utilizar um jargão da antropologia. São pessoas singulares que se sentem chamadas a partilhar duas tradições

\footnotetext{
${ }^{70} \mathrm{~S}$. DU BOULAY, La grotte du coeur, pp. 14-15.

${ }^{71} \mathrm{~J}$. DUPUIS, Verso una teologia cristiana del pluralismo religioso, Brescia: Queriniana, 1997, p. 510. E o exemplo que ele dá, em nota de rodapé, é o de Abhisiktânanda, que bem conheceu na Índia.

${ }^{72}$ C. GEFFRÉ, Profession théologien. Quelle pensée chrétienne pour le XXI siècle?, Paris: Albin Michel, 1999, p. 242. Ver ainda P.F. KNITTER, Introduzione alla teologia delle religioni, Brescia: Queriniana, 2005, pp. 448-449 (tomando como exemplo o caso de Thomas Merton).

${ }^{73}$ C. GEFFRÉ, "Double appartenance et originalité du christianisme", in D. GIRA / J. SCHEUER (org.), Vivre de plusieurs religions. Promesse ou illusion ?, Paris: L'Atelier/ Ouvrières, 2000, pp. 122-143, aqui p. 134.
} 
religiosas distintas, vivendo "na fronteira de duas comunidades e seus universos simbólicos e se sentem à vontade entre os dois"74. Em seu clássico estudo sobre o processo ritual, o antropólogo Victor Turner tratou a questão da liminaridade nos ritos de passagem. Sinaliza em sua obra que os "atributos da liminaridade, ou de personae (pessoas) liminares são necessariamente ambíguos, uma vez que esta condição e estas pessoas furtam-se ou escapam à rede de classificações que normalmente determinam a localização de estados e posições num espaço cultural"75. São entidades que não podem ser fixadas aqui ou ali, mas que se encontram "no meio", e o fato de estarem numa situação fronteiriça provoca, muitas vezes, resistência e oposição, dada a sua "invisibilidade" e seu poder "contaminador" e "perigoso"

\section{A abertura inter-religiosa}

O teólogo Paul Tillich, em clássico texto sobre a relação do cristianismo com as outras religiões, assinalou que é no âmbito da profundidade (depth) que se ganha liberdade espiritual para poder perceber a "presença do divino em todas as expressões do sentido último da vida humana"77. Foi essa a grande chave que Abhishiktânanda captou em sua trajetória de vida para o diálogo do cristianismo com o hinduísmo. O ponto de liberdade de toda religião está no fundo, escondido na guha (gruta) do coração ${ }^{78}$. Tratase do mistério de Deus ou do Real que habita o fundo do coração:

Deus está dentro, no mais profundo, no mais íntimo, no mais si de si. Não se trata de sair de si, de buscar fora para encontrar Deus, como uma pessoa que viaja em direção ao Norte, percorrendo um grande círculo, para encontrar seu irmão no Sul, não se dando conta de que estão separados apenas por uma porta... Trata-se de sair de si mesmo através de um caminho interior, para atingir o $\mathrm{Si}^{79}$.

Essa percepção não é nova na tradição cristã, estando em linha de continuidade com grandes místicos como Eckhart, Tauler e Ruysbroek. Mas

\footnotetext{
${ }^{74}$ M. AMALADOSS, "La double appartenance religieuse", in D. GIRA / J. SCHEUER (org.), Vivre de plusieurs religions, pp. 44-53, aqui p. 52.

${ }^{75}$ V.W. TURNER, O processo ritual. Estrutura e anti-estrutura, Petrópolis: Vozes, 1974, p. 117.

${ }^{76}$ Ibid., pp. 117 e 133. Ver também: D. CARRASCO, "Os que partem para uma jornada sagrada", Concilium (Br) 266/4 (1996) 10-23.

${ }^{77}$ P. TILLICH, Le christianisme et les religions, Paris: Aubier, 1968, p. 173.

${ }^{78}$ H. LE SAUX, Intériorité et révélation, p. 62; ID., Diario spirituale..., p. 358; J. STUART, Le bénédictin et le grand éveil, p. 299.

${ }^{79}$ H. LE SAUX, Diario spirituale..., p. 129. E também p. 153.
} 
também com a tradição advaita hindu. Na dinâmica de sua experiência espiritual, Abhishiktânanda pôde perceber que no "mistério do fundo", para além de todos os conceitos, estava a solução de sua dolorosa angústia. Passa a viver como um "hóspede da interioridade", trilhando com ousadia e coragem os círculos cada vez mais profundos do caminho interior, em direção ao mistério que habita o fundo da gruta (guhântara). E aconselha igualmente ao seu discípulo, Marc Chaduc, trilhar um semelhante caminho:

O essencial é penetrar no mistério interior que a Índia testemunha tão intensamente. Que você o irradie mais tarde no seio da Igreja do Ocidente ou da Igreja da Índia é secundário. Sem um 'senso' contemplativo, sua vinda à Îndia é absolutamente inútil. Venha para receber; não busque nada mais a dar do que a rosa ou o lírio. Sua interioridade irradiará por si, seja o meio cristão ou hindu. Preocupe-se em ser e não de apenas fazer (...), nem mesmo de compreender intelectualmente $(. . .)^{80}$.

Para Abhishiktânanda, a necessidade desta dimensão de fundo, tão essencial para o ser humano, era também um desafio para a igreja cristã. Não via outra possibilidade de ela se aproximar do mistério da Índia senão mediante um mergulho mais fundo no mistério da interioridade. Em carta dirigida à sua irmã, pondera:

A salvação da Igreja e do mundo não está em circunstâncias apocalípticas extraordinárias, mas no simples aprofundamento do sentido da Presença íntima de Deus. (...) Não de missões, nem palavras ou formas de vida, mas somente de uma presença incoercível, abrasante e transformante; e esta comunicação se faz diretamente, de espírito a espírito, no silêncio do Espírito. A verdade está na humildade e no não extraordinário ${ }^{81}$.

O cristão não precisa romper com Jesus para viver esse mistério de profundidade, mas necessita, sim, aprofundar sua nova percepção que se oferece através do "mistério do advaita"82. Na visão de Abhishiktânanda, Jesus aparece como sadguru, o mestre verdadeiro que aparece no tempo para conduzir o ser humano ao mistério que habita em seu interior ${ }^{83}$. Aparece igualmente como taraka, ou seja, aquele que abre condições para uma verdadeira passagem ao mundo do outro; aquele que permite a travessia ao mistério do Pai ${ }^{84}$. Essa nova percepção de Jesus foi objeto de um longo aprendizado na Índia. Em seu diário, Svâmîîî recorda que chegou inicialmente ao ambiente hindu com o intuito de anunciar a igreja e o Cristo, e

${ }^{80}$ Apud J. STUART, Le bénédictin et le grand éveil, p. 227.

${ }^{81}$ Ibid., p. 274.

${ }^{82}$ H. LE SAUX, Diario spirituale..., p. 227.

${ }^{83}$ Ibid., p. 392.

${ }^{84}$ Ibid., pp. 148-149 e 195. 
pôde descobrir que a Índia favoreceu-lhe penetrar "muito mais profundamente" o mistério de que acreditava ser o portador ${ }^{85}$.

Para alguns mestres ou amigos que encontrou em sua experiência indiana, a solução para o mergulho mais fundo no advaita puro era romper com Cristo ou o cristianismo. Era o que o aconselhava tanto o dr. Mehta como Harilal. O primeiro dizia que ele deveria abandonar a fé cristã para vencer a angústia que o dominava no período ${ }^{86}$. $\mathrm{O}$ segundo impulsionava-o para uma experiência mais radical do advaita. Ele dizia: "Não te resta senão uma coisa: rompe com os últimos vínculos que ainda o mantêm aprisionado. Estás pronto para fazê-lo. Abandona tuas orações, a tua devoção, a tua contemplação disto ou daquilo. Compreendes que $t u$ és"87. Havia, entretanto, em Abhishiktânanda um fundamento (adhisthânanda) cristão vigoroso, que o mantinha vinculado, mas sempre mantendo uma liberdade singular. $\mathrm{O}$ amor que o mantinha ligado a Jesus era muito forte:

Quer queira ou não, eu sou profundamente ligado a Jesus Cristo e também à koinonia da Igreja. É nele que o 'mistério' se revelou para mim, desde o momento de meu despertar a mim mesmo e ao mundo. É sob a sua imagem, sob o seu símbolo, que eu conheço Deus e também a mim mesmo e o mundo dos homens. Desde o momento em que me despertei para novas profundidades em mim (profundidade do si, do âtman), este símbolo desenvolveu-se maravilhosamente. Já a teologia cristã me havia favorecido descobrir a eternidade do mistério de Jesus, in sinu Patris. Mais tarde a Índia revelou-me a dimensão cósmica deste mistério, uma revelação, uma vyakti (manifestação total) do mistério, na qual insere-se a revelação judaica ${ }^{88}$.

O grande desafio dialogal intuído por Abhishiktânanda relaciona-se com a "subida ao fundo do coração". Um processo complexo e difícil, que implica despojamento radical e a ruptura dos "nós" do coração. Como sinalizou Panikkar, ocorre a "subida" quando há um despojamento verdadeiro; alcança-se o fundo quando se atinge o centro, que é o coração ${ }^{89}$. No livro dos Upanixades fala-se em "nós do coração", e do necessário desatamento dos nós, da superação dos nâmarûpa (nomes e formas) e do ahamkâra (egoísmo), para se alcançar o "Eu" fundamental (aham $)^{90}$.

\footnotetext{
${ }^{85}$ Ibid., p. 195. Em carta a Marc Chaduc, de dezembro de 1971, dizia: "Eu pensava aqui esses dias que Deus revelou-nos o seu rosto em Jesus, de forma mais bela e pura; mas no Purusa dos Upanixades, revelou-nos sua interioridade única, que é também de nós": Apud J. STUART, Le bénédictin et le grand éveil, p. 267.

${ }^{86}$ H. LE SAUX, Diario spirituale..., pp. 160-161;

${ }^{87}$ H. LE SAUX, Ricordi di Arunâchala, p. 203.

${ }^{88}$ H. LE SAUX, Diario spirituale..., p. 426.

${ }^{89}$ Ibid., p. 20 (Prefazione).

${ }^{90}$ Ibid., pp. 135 e 147. ID., Risveglio a sé, risveglio a Dio, p. 104. A menção aos "nós do coração", nos Upanixades, encontra-se em Mundaka-up, II,2 8 e 9.
} 
Se Deus está no fundo do coração, sua presença é universal e seu mistério revelador é inusitado. Em página de seu diário, Abhishiktânanda reconhece isso com clareza:

Deus não é mais aqui e menos lá; essas são idéias do homem míope e suas distinções. Deus se faz presente tanto no vôo do inseto como na contemplação do teólogo ou no ato de amor místico. Deus não estava menos em Yâjñâvalkya que em Isaías, não estava menos em Sâkyamuni (o Buda) que em Paulo de Tarso ${ }^{91}$.

Há um incontornável pluralismo religioso, e Abhishiktânanda tem plena consciência disso. O desafio que busca responder em sua vida e em sua prática espiritual é o de um encontro das religiões em nível de maior profundidade, é o de buscar a Fonte comum que as irmana. A grande pista está no mistério do advaita, presente no recinto mais íntimo seja do hinduísmo ou do cristianismo. É na dimensão de profundidade que estas duas tradições podem encontrar a "não-dualidade" que as preside. E isso vale também para o diálogo com as outras religiões. Para Abhishiktânanda, "não é na redução de suas crenças e práticas que as religiões revelam sua unidade (...), mas em algo de mais profundo, de inexprimível e indizível, avyakta, e que não pode jamais tornar-se vyakta, essencialmente não manifesto e não manifestável"92. Há entre as diversas religiões uma "misteriosa correspondência". Não há porque entendê-las como "sistemas paralelos" ou hierarquicamente distintos, como se só o cristianismo fosse portador do "passo definitivo". Todas participam do "darœana (visão) do mistério que advém" e são "verdadeiras em seu âmbito" ${ }^{\prime 93}$.

\section{Conclusão}

O clássico documento Diálogo e Missão, do então Secretariado para os Não-Cristãos, identificou o diálogo da experiência religiosa como aquele que se dá em nível de maior profundidade ${ }^{94}$. O itinerário de buscadores como Abhishiktânanda (Henri le Saux), Panikkar, Thomas Merton, Louis Massignon e tantos outros, expressa a riqueza de uma tal experiência e o seu grande potencial dialogal. São figuras humanas excepcionais que se dispuseram ao exercício de "auto-exposição ao outro" sem romperem com o "auto-respeito genuíno", ou seja, o respeito à particularidade da própria

\footnotetext{
${ }^{91}$ H. LE SAUX, Diario spirituale..., p. 222.

${ }_{92}$ Apud M-M. DAVY, Henri le Saux. Le passeur entre deux rives, p. 173.

${ }^{93}$ H. LE SAUX, Diario spirituale..., p.155.

${ }^{94}$ SECRETARIADO PARA OS NÃO-CRISTÃOS, A Igreja e as outras religiões. Diálogo e Missão, São Paulo: Paulinas, 2001, n. 35.
} 
tradição religiosa. No caso específico de Abhishiktânanda, objeto desse artigo, há que reconhecer sua extraordinária generosidade e ousadia dialogal. Trata-se de alguém que viveu em profundidade a experiência do encontro com a alteridade. Não se restringiu a viver o diálogo como um exercício de assimilação de elementos de exterioridade da outra tradição, mas movido por sede mais intensa, buscou arrojar-se numa dinâmica de aprendizado ainda mais radical, vivendo a autenticidade do advaita. Foi um peregrino que assumiu o "risco" de uma travessia novidadeira, marcada pelo encontro criador de uma experiência religiosa pontuada por duas tradições distintas. Longe de significar uma experiência relativizadora da tradição, o seu itinerário revela, antes, a densidade e a riqueza de uma experiência espiritual e de uma "comunicação em profundidade" que não se detém diante das diferenças.

Faustino Teixeira é doutor em Teologia pela Pontifícia Universidade Gregoriana (Roma). Professor do Programa de Pós-Graduação em Ciência da Religião da Universidade Federal de Juiz de Fora (MG) e Pesquisador do CNPq. É autor de vários livros entre os quais: Teologia das religiões:Uma visão panorâmica, São Paulo: Paulinas, 1995; Os encontros intereclesiais de CEBs no Brasil, São Paulo: Paulinas, 1996; e ultimamente a organização das obras: No limiar do mistério, São Paulo: Paulinas, 2004; Nas teias da delicadeza, São Paulo: Paulinas, 2006; Sociologia da religião, $2^{a}$ ed., Petrópolis: Vozes, 2007; O canto da unidade. Em torno da poética de Rûmî, Rio de Janeiro: Fissus, 2007.

Endereço: Rua Antônio Carlos Pereira, 328 (Condomínio Tiguera) 36071-120 Juiz de Fora, MG e-mail: faustino.teixeira@ufjf.edu.br 